\title{
The Joseph P. Day Gift
}

ThE generosity of Mr. Joseph P. Day has recently enabled the Business Historical Society to buy an interesting little collection of pamphlets on transportation. The material divides itself into two groups, one consisting of four items on the Chesapeake and Ohio Canal, ranging in date from 1827 to 1832 ; and the other of a much larger number of railroad papers, for the most part dated between the time of the Civil War and 1880 . The first group deserves particular mention for the bearing of one item on the question, much in debate at the time, however obvious the answer may seem to us of the present century, of whether the railroad or the canal should be adopted by the country as its means of transportation. That question was decided essentially by the contest between this Chesapeake and Ohio Canal and the Baltimore and Ohio Railroad. When on the Fourth of July, 1828, President Adams broke ground for the canal and Charles Carroll of Carrollton lifted the first spadeful of earth for the Baltimore and Ohio, popular opinion was all in favor of canals. But the protracted litigation which followed as to the right of way to the narrow left bank of the Potomac, where there was not room enough between the cliffs and the water for both works, gave the railroad time to demonstrate its superiority by dint of rapid improvement, and left the canal company bankrupt and deprived of Federal support. One of the pamphlets in the collection contains some of the correspondence relating to this controversy.

Among the later items, one from the East calls for mention, comprising several speeches and arguments by Franklin B. Gowen (president for fourteen years of the Philadelphia and Reading Railroad), and also a report of the trial of several members of the Ancient Order of Hibernians, commonly known as the "Mollie Maguires." Mr. Gowen undertook and succeeded in the task of putting an end to the depredations of this turbulent organization in the mining region in which his railroad operated. In his speeches he discusses at length the ruinous policy of the trunk lines in competing, not always honestly, for the business of the Standard Oil Company.

Outstanding in the railroad group are a number of pamphlets on early transportation in the West. Among the most interesting of the items relating to the "granger" railroads is one on the Chicago 
and Northwestern, in which some Wisconsin legislators, in fear and trembling for the interests of the State, most "strongly, earnestly and emphatically protest" against the extension of the Northwestern's policy of consolidation in Wisconsin. Others have to do with land grants to these western roads.

The far-western group forms a most interesting part of the collection. One pamphlet defends the position of the majority of the Committee on Pacific Railroads in regard to a bill for granting aid to the Northern Pacific and Atlantic and Pacific Railroad Companies (the latter being a southern route, now part of the St. Louis and San Francisco), against an attack by the minority of that committee. Among other things, the majority argues that a nation cannot better invest its capital than in aiding its highways, that uninterrupted communication across the continent cannot be secured by one railroad to the Pacific, that the new roads will much more than pay for themselves, and that they will eventually lead to so close a welding of Canadian and Mexican with American interests that annexation will inevitably follow. Other representative items are the pamphlet containing speeches by the Hon. Otho R. Singleton and the Hon. E. D. Standiford in favor of granting government aid to the Texas Pacific Railroad, and that reprinting some of the testimony taken by the United States Pacific Railway Commission in the Congressional Investigation on the Management of the Pacific Railroads, which investigation was precipitated by the maturing of the government bonds of the Union Pacific in I899.

Since the above was written, Mr. Day has again come forward with a valuable contribution to the Society's material. This is described in the article - in this issue - on the Scientific American.

\section{Early California}

THE Library has just added to its material relating to the early history of California the second volume of "The State Register and Year Book of Facts" (I 859). It has much valuable statistical material relating to the political, social and economic aspects of the life of the state at that period; besides other interesting local data. Any material on early California is a welcome accession. 